\title{
Does the Role of Observer Countries in the Regional Trade Agreement matter for Intra-
}

\section{Regional Trade?}

\author{
Dakshina G. De Silva* $\quad$ Soon-Cheul Lee $^{\dagger}$
}

July 12, 2017

\begin{abstract}
This paper investigates the effects of trade by observed economies on the intra-regional trade by SAARC members using PPML gravity models with panel data over the period 2008-2014. Eight SAARC members and eight observed countries, including the EU, are analyzed in capturing the trade effect of observed economies on intra-regional trade in SAARC. This paper provides an empirical measure of observers' trade, FDI and ODA with SAARC if the exports and imports of observers to/from SAARC have positive or negative signs for intra-regional exports and imports. The results show that the exports and imports of observers to SAARC members have positive effects on bilateral exports among the members. The FDI of observers reduces the bilateral intra imports in SAARC and ODA also has a negative effect on bilateral exports among the members. These results imply that the imports by SAARC members from observer countries increase intra-regional trade in the region. The FDI and ODA increase and decrease intra-regional trade in SAARC, respectively, implying that the policies for both FDI inflow from observers and efficient aid management are needed to increase regional welfare. The study also recommends that trade between SAARC members and its observers help to increase intra-regional trade in SAARC.
\end{abstract}

Keywords: intra-regional trade, the role of observers, regional trade agreement, SAARC, trade JEL: F15, F14

\footnotetext{
* Department of Economics, Lancaster University, Lancaster, LA1 4YX, UK

${ }^{\dagger}$ Corresponding author: Professor, Busan University of Foreign Studies, S. Korea, sclee@ bufs.ac.kr
} 


\section{Introduction}

Regional economic cooperation establishes a regional trade agreement (RTA) to receive exclusive benefits from trade creation and trade diversion effects that the RTA generates. Many studies have provided theoretical and empirical evidence that the RTA stimulates and expands the mutual or intra-regional trade as the RTA grants tariff and non-tariff concessions to member countries. Lipsey (1960) argued that a custom union increases intra-bloc trade and gives exclusive benefits to the members of the RTA, while trade with non-members would be reduced. Schiff (1999) also provides evidence that a preferential trade agreement increases mutual trade among the members.

The complementary trade relations among members are a factor for expanding intraregional trade (Chandran 2010). That is, it indicates that, in order to expand intra-regional trade, the trade structure would be complementary rather than substitutive. Furthermore, it is argued that complementary trade relations lead to relatively less trade diversion effects with non-members in regional trade.

However, there is an argument that it is not easy for intra-regional trade that may link with regional economic development as the regional trade agreement consists of developing countries (Rajapakse and Arunatilake 1997). India has the largest share of intra-SAARC trade while those of the other members are very small and limited in variety. The trade dependence of SAARC countries on non-member countries is high due to the similarity of trade products of SAARC countries. They usually export primary goods or labor-intensive products such as agricultural products, textiles, minerals, and so on. As the similarity of trade goods is relatively high among SAARC countries, the trade-creation effects would be small due to the substitute structure. However, the export products of SAARC members to developed countries are strictly complementary and lead to more trade.

Thus, the trade with non-members rather than with those in the region is more significant in the SAARC region. Moreover, the observer countries of SAARC are the most developed countries or highly industrialized countries in the manufacturing sector, and this increases the importance of trade with SAARC countries.

Thus, it is important to examine how trade relations between SAARC members and 
observer countries are set up in view of regional trade expansion and economic growth through trade. If they have a complementary relation rather than a substitutive one, then the intra-regional trade among the members will expand. The SAARC countries increase their welfare as they expand their trade with observer countries while their trade relations with the rest of the world economies decline as the trade diversion effect against third countries is diminished. If the substitutive relation is higher than the complementary one, the trade with observers and members may be reduced.

Even though they established an RTA, SAARC members have the least trade diversities and low complementary but high substitutive relations among members while they have complementary relations and very high variety with observer countries.

The aim of this study is to investigate whether the trade of SAARC members with observers affects intra-SAARC trade positively or negatively. If trade with observers affects intra-regional trade, then SAARC members achieve economic development through trade with observers.

This study adopts a similar method to examine the trade relationships between members and observers in a regional bloc with the gravity model. The gravity model has been frequently applied to analyze international trade relations. However, the scope of much of these studies has been limited to investigating trade relations within a region or a trading bloc (for example Feenstra et al. 1998, Anderson and van Wincoop 2003, McCallum 1995, and so on). Few studies have examined the gravity model against a group of trading partners but potential RTA members. Our contribution to the gravity model literature is as follows.

First, while researchers have extensively examined bilateral trade with a trading partner or a group of trading partners, not much has been done to study potential regional trade partners. As a result, it is not clear whether gravity bilateral trade variables are more sensitive to potential regional trade partners - the observer members who are yet to join the RTA. Many studies explore the effect of RTAs or FTAs. Few studies distinguish between members and observer members or potential bloc-trade partners.

Second, the role of multilateral trade agreements is important to the economic integration process, but SAARC has received limited attention. There are a few studies that explore trade relations in the SAARC region such as Rajapalse and Arunatilake (1997) who analyzed trade 
barriers to intra-SAARC trade from a Sri Lankan perspective.

Third, some income variables, such as the difference of incomes or the difference of economic growth in terms of per capita incomes, are added in the generalized gravity model. These variables have strong economic significance, but are highly correlated and pose multicollinearity problems. Estimation of a model with multi-collinear variables leads to inaccurate estimation of parameters (Vogelvang 2005). This paper uses the recent panel data technique to avoid this multi-collinearity problem that is usually present in the gravity model.

Fourth, PPML (Poison Pseudo Maximum Likelihood estimator) will be used to remove the bias against zero trade and heteroskedasticity. The trade data include many zeroes indicating no trade or a small amount trade. If the log of the gravity model is used for estimation, the error terms have correlated with the independent variable or have omitted variables problems, yielding inconsistent results. In order to solve these problems, Silva and Tenreyro (2006) argued that PPML will be used to obtain consistent estimates instead of the log of the gravity model.

Fifth, the study also examines the effects of FDI and ODA flow from observers into SAARC member countries on intra-regional trade. The most FDI and ODA inflows to SAARC come from observer countries.

The study finds that the observers' exports to SAARC member countries have a positive impact on bilateral exports among SAARC countries while the others are statistically insignificant. These results imply that imports by SAARC members from observer countries expand intra-regional trade and the FDI and ODA inflows from observers increase and decrease the trade in the region, respectively.

The structure of the paper is as follows. The second section will discuss trade relations between SAARC members and observer countries. The third section presents the empirical model and describes the data used for the analysis. The empirical results are shown in the fourth section. The final section concludes the study and identifies some implications. 


\section{SAARC trade relations with observer partners}

The South Asian Association for Regional Cooperation (SAARC) is the regional intergovernmental organization founded by Bangladesh, Bhutan, India, Maldives, Nepal Pakistan and Sri Lanka in 1985 (Afghanistan joined SAARC in 2007). SAARC has nine observers: Australia, China, EU, Iran, Japan, Mauritius, Myanmar, South Korea, and USA. The objectives of SAARC are to promote regional economic development and integration in the region through the principles of the United Nations Charter and Non-Alignment. SAARC comprises $2 \%$ of the global economy, $23 \%$ of the world's population, and $3 \%$ of the world's area as of 2015. It launched the South Asian Free Trade Area (SAFTA) in 2006, leading to the formation of a Customs Union, Common Market, and Economic Union.

SAFTA plans to gradually move towards a South Asian Economic Union, but the current political and economic relations in the region are not encouraging and it may be difficult to achieve this target. Intra-SAARC trade stands at just $7.6 \%$ and $3.9 \%$ on the share of intraregional exports and imports in overall trade in SAARC, respectively. While the total exports and imports of SAARC members are, on average, US\$ 318 million and US\$ 504 million, intra-SAARC exports and imports are US\$ 24 million and US\$ 19 million over 2008-2014. However, those of the observers in SAARC are US\$ 170 million and US\$ 225 million, accounting for $53.7 \%$ and $44.6 \%$ of the total amount of SAARC members' exports and imports, respectively. Among the member countries, India has the most exports and imports in the region in terms of both total trade with the world and observers, accounting for $81.7 \%$ and $79.5 \%$ of the total amount, $5.3 \%$ and $0.5 \%$ of intra-regional trade, and $43 \%$ and $32.3 \%$ of 
observers, compared to the total exports and imports of SAARC members. The most important country in intra-regional trade is Sri Lanka rather than India. The others are relatively dismal. The details are presented in Table 1.

Table 1: Average exports and imports of SAARC Members and Observers over 2008 2014

(Unit: US\$ million)

\begin{tabular}{|c|c|c|c|c|c|c|}
\hline \multirow{2}{*}{ Country } & \multicolumn{2}{|c|}{ Total Trade by Members } & \multicolumn{2}{|c|}{$\begin{array}{c}\text { Intra- regional Trade by } \\
\text { Members }\end{array}$} & \multicolumn{2}{|c|}{$\begin{array}{c}\text { SAARC Trade by } \\
\text { Observers }\end{array}$} \\
\hline & Exports & Imports & Exports & Imports & Exports & Imports \\
\hline Afghanistan & 0.45 & 5.85 & 0.38 & 1.50 & 0.06 & 1.79 \\
\hline Bangladesh & 23.96 & 32.34 & 0.34 & 3.05 & 14.74 & 33.29 \\
\hline Bhutan & 0.39 & 0.64 & 0.42 & 0.58 & 0.00 & 0.06 \\
\hline India & 260.61 & 401.28 & 17.38 & 2.89 & 137.57 & 163.16 \\
\hline Maldives & 0.12 & 1.45 & 0.02 & 0.31 & 0.06 & 0.23 \\
\hline Nepal & 0.88 & 5.81 & 0.72 & 4.20 & 0.20 & 0.87 \\
\hline Pakistan & 22.72 & 41.45 & 4.14 & 2.63 & 11.98 & 17.92 \\
\hline Sri Lanka & 9.18 & 15.74 & 0.93 & 4.59 & 5.93 & 7.73 \\
\hline Total & 318.32 & 504.56 & $\begin{array}{l}24.32 \\
(7.6)\end{array}$ & $\begin{array}{l}19.75 \\
(3.9)\end{array}$ & $\begin{array}{l}170.53 \\
(53.7)\end{array}$ & $\begin{array}{c}225.04 \\
(44.6)\end{array}$ \\
\hline
\end{tabular}

Note: The ratio of intra-trade by observers to total trade by members is in parentheses.

Source: trademap.org

Figure 1 shows the trend of the exports and imports of SAARC members and observers in South Asia. The total exports and imports of SAARC members to the world economy have increased sharply since 2011 and they have deficits in trade. The exports and imports of observers to SAARC member countries also show similar trends in the total exports and imports of SAARC countries. The SAARC countries have trade deficits with their observer countries. 
Figure 1: Trend of exports and imports of SAARC members and observers during the period 2008 2014

(Unit: US\$ Million)

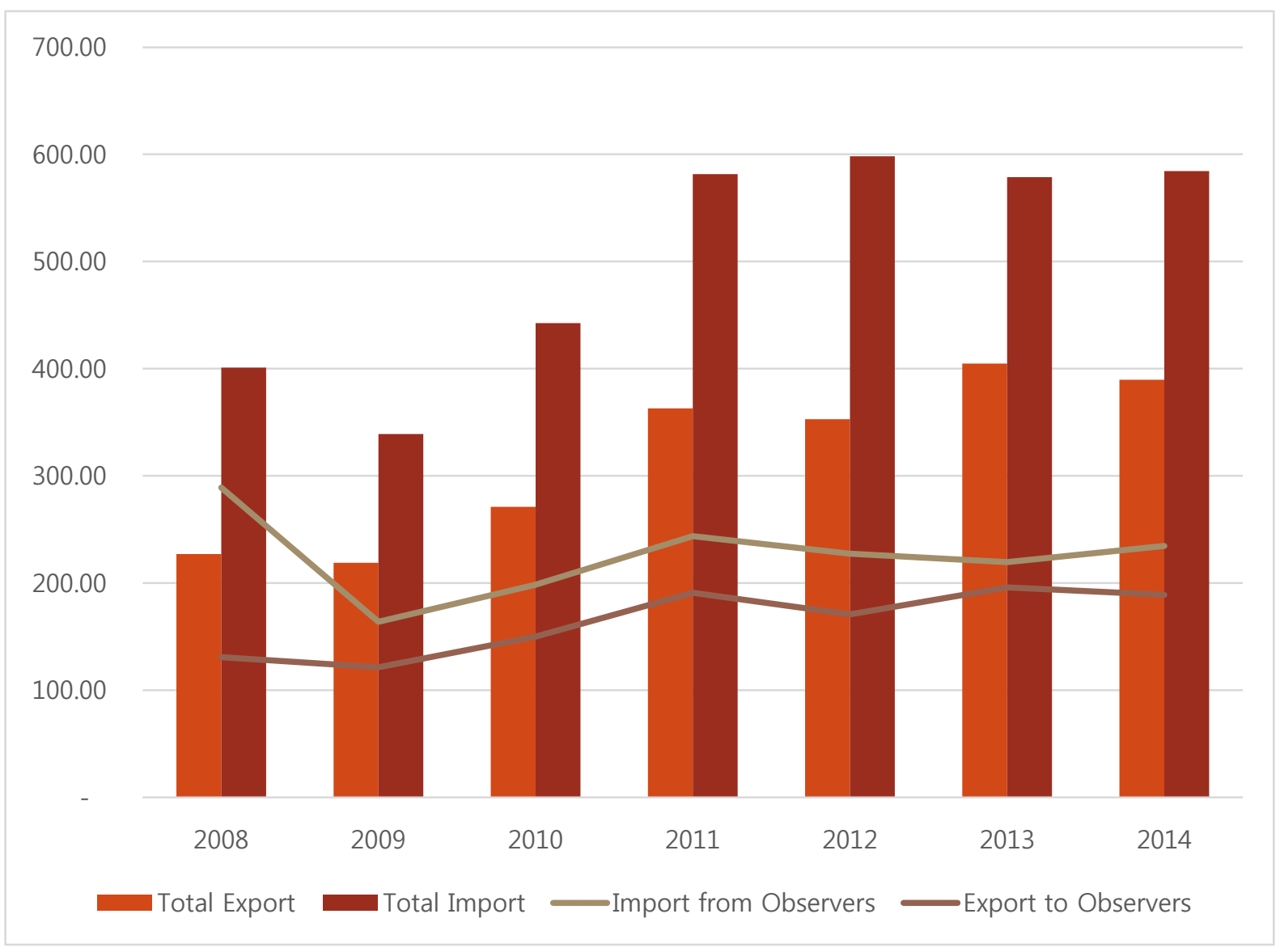

Source: trademap.org

Table 2 shows the FDI and ODA flows into SAARC member countries from the world and observers. The first and second columns indicate the net FDI inflow and total FDI inflow from the world economy and SAARC observer countries. The most beneficial country for FDI and ODA is India and the second Bangladesh and Pakistan even though they are relatively small compared to India's values. The others are very dismal. The third and fourth columns are Net ODA from the world and observer countries, respectively. The most beneficial country for ODA from the world economy is Afghanistan and India from observers. 
The ODA from observer countries to SAARC member countries accounts for most of the total ODA from the world, implying that the observer countries are important for ODA inflow in the region.

Table 2: The average FDI and ODA from observers to SAARC members over 2008 2014

\begin{tabular}{c|c|c|c|c}
\hline \multirow{2}{*}{ Country } & \multicolumn{2}{|c|}{ FDI } & \multicolumn{2}{c}{ ODA } \\
\cline { 2 - 5 } Afghanistan & $\begin{array}{c}\text { NetFDI from the } \\
\text { world }\end{array}$ & $\begin{array}{c}\text { FDI Inflow from } \\
\text { Observers }\end{array}$ & 5.98 & 1.12 \\
\hline Bangladesh & 15.14 & 2.71 & 1.63 & 1.26 \\
\hline Bhutan & 0.28 & 300.25 & 0.13 & 1.36 \\
\hline India & 302.60 & 0.00 & 2.50 & 1.59 \\
\hline Maldives & 2.51 & $11,395.00$ & 0.05 & 1.34 \\
\hline Nepal & 0.55 & 7.09 & 0.84 & 1.14 \\
\hline Pakistan & 19.44 & 2.65 & 0.02 & 1.15 \\
\hline Sri Lanka & 7.08 & 291.17 & 0.57 & 10.22 \\
\hline Total & 348.26 & -9.92 & $11,988.96$ & Observers \\
\hline
\end{tabular}

Note: The FDI and ODA of observers to SAARC are the flow, not stock or net amount. The ODA are from only the OECD countries. All values are in US \$ in millions.

Source: FDI come from UNCTAD (http://unctad.org/en/Pages/DIAE/FDI\%20Statistics/FDI-Statistics-

Bilateral.aspx) and ODA comes from WDI and OECD (http://stats.oecd.org)

\section{Empirical Model and Data}

\section{Empirical Model}

To explain the trade relations between regional trade partners (bloc members) and the potential members (observers) in the region, the traditional gravity model is applied. Timbergen (1962) proposed the following gravity equation:

$$
\operatorname{lnTR} \mathrm{ijt}_{1}=\alpha_{1}+\beta_{1} \ln Y_{i t}+\beta_{2} \ln Y_{j t}+\beta_{3} \ln D_{i j}+\varepsilon_{i j t}
$$


Where $\operatorname{lnTR}_{\mathrm{ijt}}$ is the bilateral trade amount between countriesi and $\mathrm{j}$ at time $\mathrm{t}, \ln \mathrm{Y}_{\mathrm{it}}$ and $\ln Y_{j t}$ are the GDP or market size of countries $i$ and $j$ at time $t$, and $\ln D_{i j}$ is the distance or trade cost between the two countries i and $\mathrm{j}$.

Frankel (1992) extends the traditional equation (1) further with the difference of per capita GDP and growth as the proxies for country size, development stage, or resource endowment difference.

The traditional gravity model shows that bilateral trade expands as of the large difference of economic size or market size, the nearer distance, the small difference of the endowments, and the greater similarity of economy. These variables have strong economic significance and many studies have adopted the model (Feenstra 2004, Head and Mayer 2014, Anderson 2011).

The gravity model is generalized for use in terms of logarithms, but it generates biased results due to the characteristics of trade data (Martin and Pham 2015, Silva and Tenreyro 2006). Anderson and van Wincoop (2003) argue that estimates of the traditional gravity model could be biased as the models ignore multilateral resistance factors (MRFs) such as trade agreements, common language, common colonial experience, remoteness, and adjacency. To quantify the impacts of MRFs on bilateral trade, Anderson and van Wincoop (2003) asserted that fixed effect estimation methods are used. Several authors use alternative approaches to capture the MRFs or country-specific effects for a panel of trading partners. Silva and Tenreyro (2006) argue that PPML (Poisson pseudo-maximum likelihood method) obtains consistent results while it solves the heteroskedasticity and measurement error. Related studies are Sukanuntathum (2012), Melitz (2003), Martin and Phan (2015), Shepherd (2010), and Anderson and Yotov (2012).

In line with the recent development in the estimation of the panel gravity model 
concerning these factors, this study adopts the following trade gravity model:

$$
\begin{aligned}
& \text { TR }_{i j t}=\alpha_{i j t}+\beta_{1} \text { lnDistance }_{i j}+\beta_{2} \text { Config }_{i j}+\beta_{3} \text { Comlang }_{i j}+\beta_{4} \text { Comcol }_{i j}+ \\
& \text { B5Obs.EXPoit }+\beta 6 \text { Obs.IMPoit }+\beta 7 \text { Obs.FTAoit }+\beta 8 \text { Obs.ODAoit }+ \text { cijt }
\end{aligned}
$$

lnDistance $_{\mathrm{ij}}$, Config $_{\mathrm{ij}}$, Comlang $\mathrm{ij}$, andComcol ${ }_{\mathrm{ij}}$ denote the distance, the common border, the common official language, and the common colonial experience between the member countries $\mathrm{i}$ and $\mathrm{j}$ in SAARC. Obs. $\mathrm{EXP}_{\text {oit }}$ denotes the aggregated export from observer members to SAARC country $\mathrm{i}$, and Obs. IMP $\mathrm{oit}_{\text {it }}$ is the aggregated import of observers from SAARC country i. Obs. FTA ${ }_{\text {oit }}$ and Obs. ODA oit are the aggregated FDI and ODA inflows from observers to SAARC country i, respectively.

The coefficient of lnDistance is expected to be a negative sign. As the distance between the two countries is far, the transport cost or trade cost of the two countries increases. The Config, Comlang and Comcol are expected to have a positive impact on bilateral trade flows because of the similarities between the countries which reduce trade barriers between the countries or reduce intra-trade barriers.

The exports of observers may have a positive or negative sign. If the exports of observers have a positive impact on bilateral trade with SAARC members, then they increase the trade volume and work as a complementary force. However, if it has a negative effect on intraregional trade, it plays a substitutive role in intra-regional trade in the bloc.

We assume that observer countries are relatively or highly industrialized more than SAARC member countries that mostly have trade with observer countries while the rest of world is not much related with SAARC members in terms of trade. In such a scenario, trade with observers plays an important role in the region. The intra-regional trade is replaced or 
substituted by that of observers.

Table 3. The trade relations between Observers and RTA member countries

\begin{tabular}{|c|c|c|c|}
\hline \multicolumn{2}{|c|}{} & \multicolumn{2}{|c|}{ RTA (SAARC) Countries } \\
\cline { 3 - 4 } \multicolumn{2}{|c|}{} & $\begin{array}{c}\text { Intra-regional Export } \\
\text { to Members (Bloc) }\end{array}$ & $\begin{array}{c}\text { Intra-regional Import } \\
\text { from Members(Bloc) }\end{array}$ \\
\hline Observers & $\begin{array}{c}\text { Export } \\
\text { to the Bloc }\end{array}$ & + or 0 & + or - \\
\cline { 2 - 4 } & $\begin{array}{c}\text { Import } \\
\text { from the Bloc }\end{array}$ & + or - & + or 0 \\
\hline
\end{tabular}

First of all, we take a look at the effects of the exports of observer countries to the Bloc. If the observers' exports to the Bloc have a positive effect on intra-regional exports in the Bloc, the observers' exports have a complementary effect on intra-regional trade. The members may import capital goods and major components or parts from observers (which are relatively industrialized) and they export final goods using imported products to other members though the RTA which cuts or eliminates tariffs in the region. Observers' exports might not have a negative effect on intra-regional exports, so that they might be insignificant.

Observers' exports have a complementary or substitutive relationship to observers' imports from members if a member imports from observers such items as capital goods and components or parts to make final goods while the country imports raw materials with RTA concession rates from members which are relatively cheap and abundant. This makes for a positive relationship between observers' exports and bilateral imports between members. Observers' exports to the Bloc work negatively to affect bilateral imports in the region when the bilateral imports substitute imports from observers. Observers' products might be cheaper and better quality than those of members. For example, Chinese products are cheaper and better than those of SAARC members. This case has a substitutive effect on bilateral imports 
in the region.

Second, observers' imports from the Bloc have a complementary or substitutive relationship with bilateral exports and imports between members in the region. If a member has the capability to produce and export goods to observers, then the country also exports its products to other members. However, as the country exports products such as raw materials or natural resources to observers, the country may reduce its exports to members due to their scarcity. The former will have a positive sign, but the latter will have a negative sign for bilateral exports between members.

When a member exports its products to observers, it needs more components or raw materials and procures them from within the region. This leads to more bilateral imports between members, resulting in a positive sign.

Observers' FDI and ODA have positive or negative signs. If the FDI and ODA help to expand intra-regional trade, they will have positive signs, but negative signs otherwise.

\section{Data}

This study analyses the effects of observers' trade on the bilateral trade flow among SAARC members over the period 2008 to 2014 for eight members and eight observers. Appendix A lists the countries analyzed. Table 1 also describes the variables and data sources. The data of exports and imports come from the International Trade Center. Distance, contiguity, common official language, and colonial link between the two countries are from the CEPII institute. The data for FDI and ODA come from the database in UNCTAD and OECD. The FTA data are from the WTO, which lists agreements that have been officially notified over the period analyzed. More details are described in Table 4. 
Table 4: Variables Description and Data Source

\begin{tabular}{|c|c|}
\hline Variables & Description and Sources \\
\hline Export $_{i j t}$ & $\begin{array}{l}\text { Bilateral merchandise export among SAARC members in US } \\
\text { Billion \$. (ICT) }\end{array}$ \\
\hline Import $_{i j t}$ & $\begin{array}{l}\text { Bilateral merchandise import among SAARC members in US } \\
\text { Billion \$. (ICT) }\end{array}$ \\
\hline $\operatorname{lnDist}_{i j}$ & Log distance between $i$ and $j$ countries of SAARC (CEPII) \\
\hline Obs. EXP $P_{o i t}$ & $\begin{array}{l}\text { Total exports of observers to SAARC countries in US Billion } \$ \text {. } \\
\text { (ICT) }\end{array}$ \\
\hline Obs. IMP $P_{\text {oit }}$ & $\begin{array}{l}\text { Total imports of observers from SAARC countries in US Billion } \$ \text {. } \\
\text { (ICT) }\end{array}$ \\
\hline Obs.FDI $I_{\text {oit }}$ & $\begin{array}{l}\text { Total FDI inflow of observers to SAARC countries in US Million } \$ \text {. } \\
\text { (UNCTAD) }\end{array}$ \\
\hline Obs. ODA $A_{\text {oit }}$ & $\begin{array}{l}\text { Total FDI inflow of observers to SAARC countries in US Million \$. } \\
\text { (OECD) }\end{array}$ \\
\hline Config & $\begin{array}{l}1 \text { if the two countries in SAARC share a common border or zero } \\
\text { otherwise(CEPII) }\end{array}$ \\
\hline Comlang & $\begin{array}{l}1 \text { if the two countries in SAARC share a common official language } \\
\text { or zero otherwise (CEPII) }\end{array}$ \\
\hline Comcol & $\begin{array}{l}1 \text { if the two countries have ever had a colonial link, } 0 \text { otherwise } \\
\text { (CEPII) }\end{array}$ \\
\hline$P A K-C H N F T A$ & $\begin{array}{l}\text { Pakistan and China FTA(WTO), since } 2008 \text {, Pakistan=1 or zero } \\
\text { otherwise }\end{array}$ \\
\hline IND-KOR FTA & $\begin{array}{l}\text { India and Korea FTA(WTO), since } 2010 \text {. India=1 or zero } \\
\text { otherwise }\end{array}$ \\
\hline IND-JAN FTA & $\begin{array}{l}\text { India and Japan FTA (WTO), since 2011. India=1 or zero } \\
\text { otherwise }\end{array}$ \\
\hline APTA & $\begin{array}{l}\text { Asia-Pacific Trade Agreement(WTO), } 1 \text { if countries are } \\
\text { Bangladesh, India, Sri Lanka or zero otherwise, since } 2004\end{array}$ \\
\hline
\end{tabular}

Note: ITC-International Trade Center, https:trademap.org

UNCTAD-United Nations Conference on Trade and Development

CEPII- Centre d'Etudes Prospectives et d'Informations Internationales, http://www.cepii.fr.

WTO-World Trade Organization, http://rtais.wto.org/UI/PublicMaintainRTAHome.aspx

Table 5 provides summary statistics for these eight SAARC members and eight observers.

On average, the bilateral merchandise export and import values among SAARC members are about $\$ 3$ billion and $\$ 2.5$ billion per country, respectively. Similarly, the total value of 
observers' exports and imports to/from SAARC are $\$ 189.9$ billion and $\$ 260$ billion per country, respectively. The total value of observers' FDI inflow and ODA inflow to SAARC members are $\$ 1.5$ billion and 0.01 billion, respectively. In the next section, the empirical results are presented.

Table 5: Summary Statistics

\begin{tabular}{|l|r|r|r|r|r|}
\hline \multicolumn{1}{|c|}{ Variable } & \multicolumn{1}{c|}{ Obs } & \multicolumn{1}{c|}{ Mean } & \multicolumn{1}{c|}{ Std. Dev. } & \multicolumn{1}{c|}{ Min } & \multicolumn{1}{c|}{ Max } \\
\hline Exports & 392.0 & 3.0 & 8.4 & 0.0 & 59.5 \\
\hline Imports & 392.0 & 2.5 & 7.0 & 0.0 & 45.7 \\
\hline lnDistance & 392.0 & 7.4 & 0.7 & 5.9 & 8.1 \\
\hline Obs.EXP & 392.0 & 189.9 & 423.9 & 0.0 & 1624.5 \\
\hline Obs.IMP & 392.0 & 260.6 & 502.6 & 0.1 & 1744.8 \\
\hline Obs.FDI & 392.0 & 1498.6 & 4583.6 & -245.2 & 18785.3 \\
\hline Obs.ODA & 392.0 & 0.011 & 0.013 & 0.000 & 0.051 \\
\hline
\end{tabular}

\section{Empirical Results}

This section provides the empirical results from the gravity models of the observer effects on export and import flows in the RTA. Table 6 presents the regression estimates of the PPML models on bilateral exports among SAARC members. The first column shows the exports and imports of observers on bilateral exports or intra-regional exports among SAARC members. The second column shows the estimated results for the observers' FDI and ODA inflow effects on bilateral exports, and the third column shows the effect of observers' RTA with SAARC members on bilateral exports in the RTA bloc.

The gravity models have a very good fit for the natural distance (lnDistance). The three estimated coefficients are significant and negative as expected at the $1 \%$ or $5 \%$ confidence level and imply that bilateral trade decreases as trade cost increases.

The trade cost variables have very interesting signs that seem to have positive impacts. The 
common border (Config) is statistically insignificant (except for the first column) and the coefficient of the common language (Comlang) has a negative sign at the $1 \%$ confidence level. This is because of the relationship between India and Pakistan that have a common language. The political relationship between the two countries is very conflicted and the economic link between the two countries is also very weak (the two countries have yet to sign the MFN agreement). The relations between the two countries may preclude and negatively affect bilateral trade. The common experience of having been colonized (Comcol) has positive signs because most SAARC members have experienced British colonization.

Now, we turn to the effects of observers' exports to SAARC members on bilateral exports within SAARC. The coefficients of observers' exports to SAARC members are positively significant, providing evidence that observers' exports to SAARC members increase intraregional exports within SAARC. This suggests that SAARC members may export their products to one another as they import capital goods from observers (that are relatively industrialized countries) and export processed products to their neighbors. It implies that the observers' exports play a complementary role in increasing intra-SAARC trade.

The coefficient of observers' imports from SAARC members, however, is insignificant. This means that SAARC members don't have any supply value chains in the region to export their products to observers because they export mostly primary articles to observers.

The coefficients of observers' FDI and ODA to SAARC members have positive and negative signs at the $10 \%$ and $1 \%$ confidence level, respectively. Although the coefficient of the observers' FDI is positive, it is very small (almost zero), indicating that it does not have a significant effect on bilateral exports. The ODA has a negative sign, suggesting that the

\footnotetext{
${ }^{*}$ There are some studies that show that products produced in the region do not satisfy demand within the region. For example, India - a relatively industrialized country in the region - does not supply capital goods and durable goods to the region because of quality problems (see Kelegama 1994).
} 
inflow of observers' ODA into the region reduces intra-regional trade in the region. ${ }^{\S}$ This implies that the ODA policies may be poor in SAARC region. This is also in line with Burnside and Dollar (2000) who pointed out that aid has no positive effect on growth in the presence of poor policies.

For the FTA between observers and individual SAARC members - the Pakistan-China FTA and the India-Korea \& India-Japan FTAs_-show positive and negative signs at the $1 \%$ confidence level, implying that the FTA between Pakistan and China increases intra-regional trade in the bloc, but the FTAs between India and Korea or Japan reduce intra-regional exports. The APTA is insignificant due to the minimal trade among the APTA members.

Table 7 provides the results of estimating the gravity model with PPML for imports from observers to SAARC members. The result of the distance is inconsistent with the gravity model as the coefficients are all insignificant. The coefficient of the common border, which was insignificant in previous estimates of exports, is now turning into a positive sign. Common language has a negative sign, which is consistent with the above results. The coefficients of the common colonial experience have positive signs.

Considering the role of observers' exports to and imports from SAARC members, the observers' exports are insignificant. Observers' imports from SAARC members are also insignificant.

Observers' FDI and ODA are also insignificant, implying that observers' FDI and ODA flows to SAARC members have not played any role in increasing intra-regional trade. All the coefficients of FTAs are insignificant. The results suggest that FTAs between individual SAARC members and observers do not cause an increase in intra-regional imports.

\footnotetext{
$\S$ Many studies have shown the negative effects of ODA on GDP and Investment. Lueth and Ruiz-Arranz (2007) show a negative correlation between ODA and GDP. Easterly et al. (2004) also find that aid has a negative effect on growth. Exemenari et al. (2008) finds foreign aids have negative effect on public investment.
} 
Table 6: The effect of observers on bilateral exports in SAARC

\begin{tabular}{|c|c|c|c|}
\hline VARIABLES & $\begin{array}{c}(1) \\
\text { Exports }\end{array}$ & $\begin{array}{c}(2) \\
\text { Exports }\end{array}$ & $\begin{array}{c}(3) \\
\text { Exports }\end{array}$ \\
\hline lnDistance & $\begin{array}{c}-1.3407 * * * \\
(0.3821)\end{array}$ & $\begin{array}{c}-1.1548 * * \\
(0.4521)\end{array}$ & $\begin{array}{c}-1.3365 * * * \\
(0.4735)\end{array}$ \\
\hline Contig & $\begin{array}{l}1.4971 * * \\
(0.7460)\end{array}$ & $\begin{array}{c}0.8405 \\
(0.6676)\end{array}$ & $\begin{array}{c}0.5694 \\
(0.6877)\end{array}$ \\
\hline Comlang & $\begin{array}{c}-3.9431 * * * \\
(0.5134)\end{array}$ & $\begin{array}{c}-1.8068 * * * \\
(0.4173)\end{array}$ & $\begin{array}{c}-2.0770 * * * \\
(0.3986)\end{array}$ \\
\hline Comcol & $\begin{array}{c}4.7632 * * * \\
(0.6423)\end{array}$ & $\begin{array}{c}1.6691 * * * \\
(0.4104)\end{array}$ & $\begin{array}{c}1.8212 * * * \\
(0.5094)\end{array}$ \\
\hline Obs.EXP & $\begin{array}{c}0.0010 * * * \\
(0.0004)\end{array}$ & $\begin{array}{c}0.0025 * * * \\
(0.0006)\end{array}$ & $\begin{array}{c}0.0036 * * * \\
(0.0004)\end{array}$ \\
\hline Obs.IMP & $\begin{array}{c}0.0001 \\
(0.0008)\end{array}$ & $\begin{array}{l}-0.0007 \\
(0.0005)\end{array}$ & $\begin{array}{l}-0.0000 \\
(0.0007)\end{array}$ \\
\hline PAK-CHN FTA & & & $\begin{array}{l}1.5848 * * \\
(0.6198)\end{array}$ \\
\hline IND-KOR FTA & & & $\begin{array}{c}-0.4787 * * \\
(0.1906)\end{array}$ \\
\hline IND-JAP FTA & & & $\begin{array}{c}-1.1618^{* * * *} \\
(0.2580)\end{array}$ \\
\hline APTA & & & $\begin{array}{l}-0.2234 \\
(0.8490)\end{array}$ \\
\hline Obs.FDI & & $\begin{array}{c}0.0000 * * \\
(0.0000)\end{array}$ & \\
\hline Obs.ODA & & $\begin{array}{c}-9.2006^{* * * *} \\
(1.7194)\end{array}$ & \\
\hline Constant & $\begin{array}{c}7.9077 * * * \\
(2.8259)\end{array}$ & $\begin{array}{l}7.5135 * * \\
(3.1700)\end{array}$ & $\begin{array}{c}7.7779 * * * \\
(2.9660)\end{array}$ \\
\hline Observations & 392 & 392 & 392 \\
\hline R-squared & 0.9486 & 0.6616 & 0.7300 \\
\hline
\end{tabular}

Robust standard errors in parentheses $* * * \mathrm{p}<0.01, * * \mathrm{p}<0.05, * \mathrm{p}<0.1$ 
Table 7: The effect of observers on bilateral imports in SAARC

\begin{tabular}{|c|c|c|c|}
\hline VARIABLES & $\begin{array}{c}(1) \\
\text { Imports }\end{array}$ & $\begin{array}{c}(2) \\
\text { Imports }\end{array}$ & $\begin{array}{c}(3) \\
\text { Imports }\end{array}$ \\
\hline lnDistance & $\begin{array}{c}-0.0474 \\
(0.2652)\end{array}$ & $\begin{array}{c}-0.0453 \\
(0.2654)\end{array}$ & $\begin{array}{l}-0.1312 \\
(0.2205)\end{array}$ \\
\hline Contig & $\begin{array}{c}2.6176 * * * \\
(0.6774)\end{array}$ & $\begin{array}{c}2.6180 * * * \\
(0.6780)\end{array}$ & $\begin{array}{c}2.5523 * * * \\
(0.6921)\end{array}$ \\
\hline Comlang & $\begin{array}{c}-0.7337 * * \\
(0.3595)\end{array}$ & $\begin{array}{c}-0.7332 * * \\
(0.3590)\end{array}$ & $\begin{array}{l}-0.1080 \\
(0.4969)\end{array}$ \\
\hline Comcol & $\begin{array}{c}1.3896 * * \\
(0.6217)\end{array}$ & $\begin{array}{l}1.3839 * * \\
(0.6177)\end{array}$ & $\begin{array}{c}1.1714 * * * \\
(0.3539)\end{array}$ \\
\hline Obs.EXP & $\begin{array}{c}0.0001 \\
(0.0009)\end{array}$ & $\begin{array}{c}0.0001 \\
(0.0009)\end{array}$ & $\begin{array}{c}0.0001 \\
(0.0012)\end{array}$ \\
\hline Obs.IMP & $\begin{array}{c}-0.0009 \\
(0.0009)\end{array}$ & $\begin{array}{c}-0.0009 \\
(0.0009)\end{array}$ & $\begin{array}{l}-0.0012 \\
(0.0015)\end{array}$ \\
\hline PAK-CHN FTA & & & $\begin{array}{l}-0.6218 \\
(0.5903)\end{array}$ \\
\hline IND-KOR FTA & & & $\begin{array}{l}-0.2297 \\
(0.4796)\end{array}$ \\
\hline IND-JAP FTA & & & $\begin{array}{c}0.4516 \\
(0.8581)\end{array}$ \\
\hline APTA & & & $\begin{array}{c}0.4081 \\
(0.3754)\end{array}$ \\
\hline Obs.FDI & & $\begin{array}{c}-3.1347 \\
(3.2271)\end{array}$ & \\
\hline Obs.ODA & $\begin{array}{c}-0.3171 \\
(2.0118)\end{array}$ & $\begin{array}{c}-0.3062 \\
(2.0200)\end{array}$ & $\begin{array}{c}0.4180 \\
(1.6393)\end{array}$ \\
\hline Observations & 392 & 392 & 392 \\
\hline R-squared & 0.2689 & 0.2682 & 0.2604 \\
\hline
\end{tabular}

Robust standard errors in parentheses

$* * * \mathrm{p}<0.01, * * \mathrm{p}<0.05, * \mathrm{p}<0.1$

\section{Conclusion}

The RTA plays a role in increasing intra-regional trade in the bloc. However, an RTA among developing countries such as SAARC members might not play a significant role in active intra-regional trade when the volume of trade between members is small, but that with observers is relatively large. This paper began with the question: Does the trade of observers with RTA members increase intra-regional trade in a region like SAARC? This paper 
empirically analyzes how the economic cooperation of observers with an RTA's members affects intra-regional trade. The exports, imports, FDI, and ODA of eight observer countries with eight SAARC member countries are used for empirical analyses with PPML. Few studies investigate the observers' effect on intra-regional trade in an RTA, and previous studies have mostly focused on intra-regional trade among RTA members or members versus non-members.

This paper finds that observers' exports to SAARC members have positive effects on intraregional exports. As SAARC members import capital goods from observers, they use the imported goods to expand their exports to other region members. SAARC members' exports to observers might also increase bilateral imports as they export primary goods to observers.

FDI inflows into SAARC from observers increase bilateral exports in the region, but ODA decreases bilateral exports within SAARC. The FTAs between SAARC members and observers have positive and negative effects on bilateral exports within the bloc.

These results suggest that, in order to increase exports within SAARC, SAARC members import capital goods to expand production from relatively highly industrialized observer countries. This means that the export capability of SAARC members is the most important factor in expanding intra-regional trade. They also need more powerful policies to induce investment from observers. However, a more efficient management system for ODA needs to be introduced. FTAs with developing observers could expand intra-SAARC trade, while those with relatively industrialized countries reduce such trade. 


\section{References}

Anderson, J. E., \& van Wincoop, 2003, "Gravity with gravitas: A solution to the border puzzle," American Economy Review 93(10), pp.170-192

Anderson, J. E and Y. Yotov, 2012, "Gold standard gravity" Working Paper 17835, National Bureau of Economic Research, Cambridge, MA.

Anderson, James E. and E. van Wincoop, 2003, "Gravity with gravitas: a solution to the border puzzle," American Economic Review 93(1) (March), pp.170-192.

Burndise, C. and D. Dollar, 1999, “Aid, Policies, and Growth,” American Economic Review 90(4), pp.847-868.

Easterly, William, Ross Levine, and David Roodman, 2003, "New Data, New Doubts: A Comment on Burnside and Dollar's 'Aid, Policies, and Growth'.” NBER Working Paper 9846.

Ezemenari, K. E. Kebede \& Labiri, S., 2008, "The Fiscal Impact of Foreign Aid in Rwanda:

A Theorectical and Empirical Analysis," Policy Research Working Paper 4541. World Bank.

Feenstra, R, C., Markusen, J, R., \& Rose, A. K., 1998, "Understanding the home market effect and the gravity equation: The role if differenctiating goods," NBER Working Paper Series 6804.

Feenstra, Robert, 2004, Advanced International Trade. Princeton University Press.

Frankel 1992

Head, K. and T. Mayer, 2014, "Gravity equations: workhorse, toolkit and cookbook," In: Gopinath, Helpman, Rogoff (Eds.), Handbook of International Economics 4, pp.131201.

Kalegama, J. B., 1994, "Will the SAARC Preferential Trading Arrangement Expand Mutual Trade in South Asia?" Economic Review (May/June), pp.45-49.

Lipsey, R., 1960, “The theory of customs unions: A general survey,” Economic Journal 70, pp.498-513.

Martin, W. and C. S. Pham, 2015, "Estimating the Gravity Model When Zero Trade Flows Are Frequent and Economically Determined," World Bank Policy Research Working Paper 7308.

McCallum, J., 1995, "National borders matter: Canada-US regional trade pattern," The 
American Economic Review 85(3), pp.615-623.

Melitz, M., 2003, "The impact of trade on intra-industry reallocations and aggregate industry productivity."Econometrica 71(6), pp.1695-725.

Rajapakse, R. and N. Arunatilake, 1997, "Would a Reduction in Trade Barriers Promotion Intra-SAARC Trade?: A Sri Lanka Perspective,” Journal of Asian Economic 8(1), pp.95-115.

Lueth, Erik and Marta Ruiz-Arranz. 2007, “Are Workers' Remittances a Hedge Against Macroeconomic Shocks? The Case of Sri Lanka." IMF Working Paper WP/07/22.

Shepherd, B., 2010, "Geographical diversification of Developing Country exports."World Development 38(9), pp.1217-28.

Silva, J. M. C. and S. Tenreyro, 2006, “ The Log of Gravity,” The Review of Economics and Statistics 88(4), pp.641-658.

Sukanuntathum, A., 2012, "Robust Estimation of Gravity Models under Heteroskedasticity and Data Censoring," Prodcdeia-Social and Behavioral Sciences 40, pp.731-735.

Timbergen, 1962, Shaping the world economy: suggestions for an international economy policy, The twenty century fund, New York.

Vogelvang, B., 2005, Econometrics: Theory and Applications with Eviews, England: Pearson Education Ltd. 
Appendix A: The lists of countries.

\begin{tabular}{|c|c|}
\hline SAARC member Countries & SAARC observer Countries \\
\hline Afghanistan & Australia \\
\hline Bangladesh & China \\
\hline Bhutan & Burma \\
\hline India & EU \\
\hline Maldives & Japan \\
\hline Nepal & Iran \\
\hline Pakistan & S. Korea \\
\hline Sri Lanks & USA \\
\hline
\end{tabular}

